\title{
Compressive strength and durability properties of ceramic wastes based concrete
}

\author{
Fernando Pacheco-Torgal $\cdot$ Said Jalali
}

Received: 22 July 2009/ Accepted: 14 April 2010

(C) RILEM 2010

\begin{abstract}
This paper presents an experimental study on the properties and on the durability of concrete containing ceramic wastes. Several concrete mixes possessing a target mean compressive strength of $30 \mathrm{MPa}$ were prepared with $20 \%$ cement replacement by ceramic powder $(\mathrm{W} / \mathrm{B}=0.6)$. A concrete mix with ceramic sand and granite aggregates were also prepared as well as a concrete mix with natural sand and coarse ceramic aggregates $(\mathrm{W} / \mathrm{B}=0.5)$. The mechanical and durability performance of ceramic waste based concrete are assessed by means of mechanical tests, water performance, permeability, chloride diffusion and also accelerated aging tests. Results show that concrete with partial cement replacement by ceramic powder although it has minor strength loss possess increase durability performance. Results also shows that concrete mixtures with ceramic aggregates perform better than the control concrete mixtures concerning compressive strength, capillarity water absorption, oxygen permeability and chloride diffusion. The replacement of
\end{abstract}

F. Pacheco-Torgal ( $\square)$

C-TAC Research Unit, University of Minho, 4800 Guimaraes, Portugal

e-mail: torgal@civil.uminho.pt

S. Jalali

Department of Civil Engineering, University of Minho, 4800 Guimaraes, Portugal

e-mail: said@civil.uminho.pt cement and aggregates in concrete by ceramic wastes will have major environmental benefits.

Keywords Concrete Ceramic powder . Ceramic aggregates - Compressive strength . Durability performance

\section{Introduction}

In Europe the amount of wastes in the different production stages of the ceramic industry reaches some $3-7 \%$ of its global production meaning millions of tons of calcined-clays per year that are just land filled [1]. With increasing restrictions on landfills in European Union area, the cost of deposition will increase and the industries will have to find ways for reusing their wastes. Although the reutilization of ceramic wastes and has been practiced, the amount of wastes reused in that way is still negligible. Hence, the need for its application in other industries is becoming absolutely vital. Construction industry can be the end user of all ceramic wastes and in this way can contribute to solve this environmental problem. The nature of construction industry, especially the concrete industry, is such that ceramic wastes can be used safely with no need for dramatic change in production and application process. On one hand, the cost of deposition of ceramic waste in landfill will be saved and, on the other, raw materials and natural 
resources will be replaced, thus saving energy and protecting the environment. According to some authors the best way for the construction industry to become a more sustainable one is by using wastes from other industries as building materials [2, 3]. The production of cement requires high energy input (850 kcal per $\mathrm{kg}$ of clinker) and implies the extraction of large quantities of raw materials from the earth (1.7 tonnes of rock to produce 1 tonne of clinker). On the other hand the production of one tonne of cement generates 0.55 tonnes of chemical $\mathrm{CO}_{2}$ and requires an additional 0.39 tonnes of $\mathrm{CO}_{2}$ in fuel emissions, accounting for a total of 0.94 tonnes of $\mathrm{CO}_{2}$ [4]. Therefore, the replacement of cement in concrete by ceramic wastes represents a tremendous saving of energy and has important environmental benefits. Besides, it will also have a major effect on decreasing concrete costs, since the cost of cement represents more than $45 \%$ of the concrete cost. Several authors already confirmed the pozzolanic reactivity of ceramic wastes [5-7], nevertheless, research carried out so far by reusing ceramic wastes in concrete are scarce and do not evaluate concrete durability performance which is a key issue [8, 9]. Consequently the aim of this research project is the assessment of the mechanical and durability properties of ceramic waste based concrete.

\section{Experimental work}

\subsection{Materials and concrete mix design}

Ceramic wastes can be separated in two categories in accordance with the source of raw materials. The first one are all fired wastes generated by the structural ceramic factories that use only red pastes to manufacture their products, such as brick, blocks and roof tiles. The second one is all fired waste produced in stoneware ceramic such as wall, floor tiles and sanitary ware. These producers use red and white pastes, nevertheless, the usage of white paste is more frequent and much higher in volume. In each category the fired ceramic waste was classified according to the production process. This classification is reported in the following diagram (Fig. 1). The chemical compositions of ceramic pastes were analysed and results obtained are reported in Table 1. It is well established that the chemical composition of fired ceramic products is not significantly different of the one of raw materials used to make these products. Only the mineralogical composition is modified when these materials are heated. The silica and alumina are the most significant oxides present in the ceramic pastes. The variation of proportion of the silica and alumina is due to the clay used. It should be noted that the red paste shows high proportion of iron oxide responsible for the red colour of the products. In order to determine the mineralogical composition the representative samples were analysed by XRD in a Philips diffractometer PW3710 with $\mathrm{CuK} \alpha$ radiation, using secondary monochromater, automatic divergence slit and a receiving slit of $0.2^{\circ}$. Routine conditions of $40 \mathrm{kV}$ and $20 \mathrm{~mA}$ in range of $5^{\circ}-75^{\circ}$, with steps of $0.025^{\circ}$ and $1 \mathrm{~s}$, were used. Table 2 shows the results the mineralogical composition of ceramic wastes. As expected quartz and feldspars essentially compose ceramic wastes. Approximately $500 \mathrm{~kg}$ of wastes from a Portuguese ceramic company was crushed with a jaw crusher to make the ceramic aggregate. Thus, by using this system to crush ceramic wastes is possible to obtain coarse aggregates, fine aggregates and ceramic powder that after sieving can be used without additional work and with minimal cost implications. At laboratory scale the ceramic wastes were ground with a ball mill with metal balls to obtain ceramic powder. The cost of grinding is related to the amount of material grounded. For $20 \%$ cement replacement represents 3.75 of the cost of Portland cement. This indicates saving of around $17 \%$ in the cost of Portland cement in concrete. The cost of cement represents almost $45 \%$ of the concrete cost. Therefore, over all cost of concrete will be reduced by more than $7.5 \%$. This is a considerable gain in the direct savings of materials costs. The cost of deposition and land occupied by land fill has not been considered and will be an additional gain in efficiency and savings. The ceramic powders with a particle size $<75 \mu \mathrm{m}$ were chosen for the partial substitution of cement. The coarse aggregate and the sand used in the concrete mixes with cement replacement by ceramic powder were crushed granite aggregates. The water absorption, particle size distribution, density and the fineness modulus of the aggregates were determined following tests methods described in the NP EN 12620 [10]. Table 3 shows gradation and physical characteristics of these aggregates. For the production of concrete samples in 
Fig. 1 Classification of ceramic wastes by type and production process

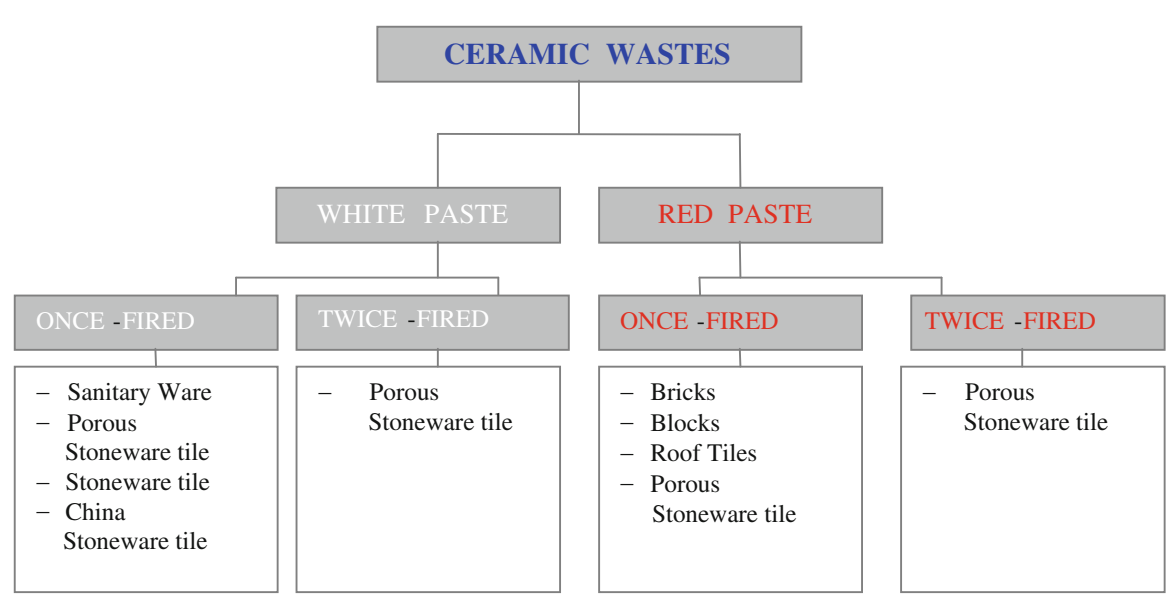

Table 1 Chemical composition of ceramic pastes (\%)

\begin{tabular}{lllllllrrr}
\hline Type & $\mathrm{SiO}_{2}$ & $\mathrm{Al}_{2} \mathrm{O}_{3}$ & $\mathrm{Fe}_{2} \mathrm{O}_{3}$ & $\mathrm{CaO}$ & $\mathrm{MgO}$ & $\mathrm{Na}_{2} \mathrm{O}$ & $\mathrm{K}_{2} \mathrm{O}$ & $\mathrm{TiO}_{2}$ & $\mathrm{Other}^{\prime}$ \\
\hline Red paste twice fired ceramic & 51.7 & 18.2 & 6.1 & 6.1 & 2.4 & 0.2 & 4.6 & 0.8 & 9.9 \\
White paste once-fired ceramic & 58.0 & 18.0 & 1.0 & 8.3 & 0.6 & 0.2 & 1.2 & 0.8 & 11.9 \\
White paste for twice-fired ceramic & 59.8 & 18.6 & 1.7 & 5.5 & 3.5 & 1.6 & 2.5 & 0.4 & 6.4 \\
Red paste for stoneware tile & 49.1 & 20.3 & 7.7 & 1.2 & 1.1 & 0.4 & 4.2 & 0.9 & 15.1 \\
White paste for stoneware tile & 65.0 & 21.3 & 1.3 & 0.2 & 0.3 & 2.5 & 3.7 & 0.2 & 5.5 \\
White paste for sanitary ware & 65.8 & 22.2 & 0.6 & 0.1 & 0.1 & 1.0 & 3.5 & 0.3 & 6.4 \\
\hline
\end{tabular}

Table 2 Mineralogical composition of ceramic wastes

\begin{tabular}{llll}
\hline Sample & Majors & Minors & Traces \\
\hline Ceramic brick & Q & $\mathrm{He}, \mathrm{C}, \mathrm{Ah}, \mathrm{Mv}, \mathrm{R}$ & $\mathrm{Fd}$ \\
Overheated brick & $\mathrm{Q}, \mathrm{Fd} 4$ & $\mathrm{Mv}, \mathrm{Cr}, \mathrm{Ah}, \mathrm{R}, \mathrm{He}$ & $\mathrm{Lm}, \mathrm{G}$ \\
White roof tile & $\mathrm{Q}, \mathrm{Mv}, \mathrm{Fd} 4$ & $\mathrm{Ah}, \mathrm{He}, \mathrm{Cr}$ & $\mathrm{G}, \mathrm{Hr}, \mathrm{Cs}, \mathrm{R}$ \\
Red roof tile & $\mathrm{Q}, \mathrm{I}(\mathrm{Mv})$ & $\mathrm{C}, \mathrm{Fd}$ & $\mathrm{Ah}, \mathrm{He}$ \\
Ceramic table for cover & $\mathrm{Q}, \mathrm{Fd}$ & $\mathrm{An}, \mathrm{He}, \mathrm{R}$ & $\mathrm{M}, \mathrm{E}$ \\
White porous stoneware tile in double baking & $\mathrm{Q}$ & $\mathrm{Fd}$, Px & $\mathrm{Cr}, \mathrm{He}, \mathrm{R}-\mathrm{Cu}, \mathrm{G}$ \\
Red porous stoneware tile in single baking & $\mathrm{Q}$ & $\mathrm{Cr}, \mathrm{HCN}, \mathrm{Fd} 2$ & $\mathrm{SF}, \mathrm{Cr}, \mathrm{Mu}, \mathrm{Hr}, \mathrm{R}, \mathrm{Mg}$ \\
White stoneware tile & $\mathrm{Q}, \mathrm{Fd} 4$ & $\mathrm{Cr}, \mathrm{Mu}, \mathrm{Px}$ & $\mathrm{Zr}, \mathrm{Mu}, \mathrm{He}, \mathrm{Ti}$ \\
Red stoneware tile & $\mathrm{Q}, \mathrm{Fd} 1$ & $\mathrm{Fd} 1, \mathrm{Cr}, \mathrm{Px}$ & $\mathrm{Ah}, \mathrm{Zr}, \mathrm{He}, \mathrm{Mg}, \mathrm{Lm}$ \\
China stoneware tile & $\mathrm{Q}$ & $\mathrm{Cu}, \mathrm{He}$
\end{tabular}

$A h$ anhydrite, $C$ calcite, $C o$ cordierite, $C s$ celsian, $C r$ cristobalite, $C u$ corundum, $E$ esseneite, $F d$ feldspars, $F d 1$ albite Ca, ord, $F d 2$ anorthite $\mathrm{Na}$, ord, $F d 3$ orthoclase, $F d 4$ anorthoclase, $G$ gehlenite, $H a$ hauyne, $H e$ hematites, $H r$ hercynite, $I$ illite, $L m$ lime, $M$ mullite, $M g$ magnetite, $M v$ muscovite, $P x$ piroxene, $Q$ quarz, $S F$ franklinite, $T i$ titanite, $Z r$ zircon

phase A, Portland cement, CEM I-32.5, complying with the NP EN 197-1 [11] was used along with both natural sand and granite aggregates. A mix design, with characteristic strength $\mathrm{f}_{\mathrm{c}}=25 \mathrm{~N} / \mathrm{mm}^{2}$ and a target mean strength $\mathrm{f}_{\mathrm{m}}=30 \mathrm{~N} / \mathrm{mm}^{2}$ was studied. Four mixes with $20 \%$ replacement of cement by ceramic powder were also prepared. Each one is named after the source of the ceramic waste: ceramic bricks (CB); White stoneware twice-fired (WSTF); sanitary ware (SW); White stoneware once-fired (WSOF). The compositions of the concrete mix used in phase $\mathrm{A}$ are described in Table 4. The equivalent ceramic 
aggregate concrete for each mix was obtained by replacing the natural aggregates with an equal volume of crushed ceramic, everything else remained the same. To have a direct comparison of concrete made with crushed-ceramic aggregate with conventional concrete, two corresponding mixes were prepared one replacing natural sand by ceramic sand (MCS) and other where coarse granite aggregate where replaced by ceramic coarse aggregate (MCCA). Because all other parameters were constant for the three mixes, it was expected that the effect of the type of coarse aggregate would be reflected in any differences in concrete properties. Table 5 shows gradation and physical characteristics of aggregates used in phase B. The ceramic aggregates were soaked in water for $24 \mathrm{~h}$ and then air-dried to a saturated surface dry condition before mixing with other ingredients. For the production of concrete samples in phase B, Portland cement, CEM I-42.5, complying with the NP EN 197-1 [11] was used. The compositions of the concrete mix used in phase B are described in Table 6. Mixing was done in a drum mixer, and workability of the fresh concrete was measured with a standard slump cone [12] immediately after mixing and a slump of $80 \mathrm{~mm}$ was obtained. This low workability is due to the high water absorption of recycled aggregates. The test specimens were cast in steel moulds and compacted on a vibrating table. Concrete specimens were demoulded 1 day after cast.

\subsection{Experimental procedures}

\subsubsection{Compressive strength}

The compressive strength was determined following the NP EN 12390-3 [13]. The specimens were cured under water at a temperature equal to $18 \pm 1^{\circ} \mathrm{C}$ until they have reached the testing ages. Tests were performed on $100 \times 100 \times 100 \mathrm{~mm}^{3}$ specimens. Compressive strength for each mixture was obtained from an average of three cubic specimens determined at the age of $7,14,28,56$ and 90 days of curing.

\subsubsection{Vacuum water absorption}

Specification to evaluate vacuum water absorption is based on water saturation of the sample under vacuum (Fig. 2). The test was performed by using cylindrical specimens $4 \mathrm{~cm}$ high and with $5 \mathrm{~cm}$ diameter. Vacuum water absorption test is carried out in two main steps: step one in which the specimens are submitted to vacuum conditions $(0.7 \mathrm{mbar})$ during $3 \mathrm{~h}$ and step two, the specimens are saturated with distilled water and again submitted to vacuum conditions during $3 \mathrm{~h}$.

Absorption is determined as follows:

$\mathrm{A}(\%)=\frac{\mathrm{W}_{\text {sat }}-\mathrm{W}_{\text {dry }}}{\mathrm{W}_{\text {sat }}-\mathrm{W}_{\text {wat }}} \times 100$

where $\mathrm{A}$ is the absorption, in percentage, $\mathrm{W}_{\text {sat }}$ weight of the saturated specimen, $\mathrm{W}_{\text {dry }}$ weight of the dry specimen and $\mathrm{W}_{\text {wat }}$ is the weight of the saturated specimen immersed in water.

\subsubsection{Capillary water absorption}

The test consists in placing the cylindrical specimens in a container with a thin water lamina in order to maintain immersed just one of the sides of the specimen. Preparation of test specimens is done as follows: after drying in an oven at $105^{\circ} \mathrm{C}$ for $48 \mathrm{~h}$, they are waterproof along the lateral surface with a fine layer of silicon in order to reduce water evaporation and guarantee capillarity water absorption. The test specimens are then placed on desiccators, for some hours, to allow the hardening of the silicon. This test his carried on according to the Portuguese Standard LNEC E393 [14]. Water absorption has been measured after $(10,30,60,90,120$, 180, 360, 480, 1440, 2880 and 4320) minutes. Capillarity water absorption coefficient was obtained from an average of three specimens.

\subsubsection{Oxygen permeability}

To evaluate the oxygen permeability a permeability cell was used (Fig. 3). This permeability cell allows to submitting specimens, with $4 \mathrm{~cm}$ high and $5 \mathrm{~cm}$ diameter, to a certain pressure, guaranteeing that the flow of oxygen through the specimen is uniaxial. The oxygen permeability (being $\eta$-oxygen dynamic viscosity $=2.02 \times 10^{-5} \mathrm{~N} \mathrm{~s} / \mathrm{m}^{2}$ ) can be determined as follow:

$\mathrm{K}=\frac{4.04 \times \mathrm{R} \times \mathrm{L} \times 10^{-16}}{\mathrm{~A} \times\left(\mathrm{P}_{2}^{2}-1\right)}$

where $\mathrm{R}$ is the oxygen flow through the specimen $\left(\mathrm{cm}^{3} / \mathrm{s}\right)$, L thickness of the test specimen $(\mathrm{m})$, A area 
Table 3 Gradation and physical characteristics of aggregates used in phase A

\begin{tabular}{llll}
\hline Sieve size & \multicolumn{3}{l}{ Cumulative percentage passing } \\
\cline { 2 - 4 } & Fine sand & Sand & $\begin{array}{l}\text { Coarse } \\
\text { aggregate }\end{array}$ \\
\hline 25.4 & 100 & 100 & 100 \\
19.0 & 100 & 100 & 100 \\
12.7 & 100 & 100 & 98.5 \\
$9.5 \mathrm{~mm}$ & 100 & 100 & 70.1 \\
$4.76 \mathrm{~mm}$ & 100 & 99.8 & 13.6 \\
$2.38 \mathrm{~mm}$ & 98.3 & 79.4 & 2.5 \\
$1.19 \mathrm{~mm}$ & 89.4 & 55.7 & 2.2 \\
$590 \mu \mathrm{m}$ & 66.9 & 37.2 & 2.0 \\
$297 \mu \mathrm{m}$ & 37.3 & 20.5 & 1.8 \\
$149 \mu \mathrm{m}$ & 13.6 & 8.3 & 1.4 \\
$74 \mu \mathrm{m}$ & 4.5 & 3.9 & 0.8 \\
Fineness modulus & 1.946 & 2.991 & 6.063 \\
Density (kg/m $\left.{ }^{3}\right)$ & 2658 & 2631 & 2619 \\
Water absorption $(\%)$ & 1.3 & 1.6 & 2.0 \\
\hline
\end{tabular}

of the section crossed by oxygen $\left(\mathrm{m}^{2}\right), \mathrm{P}_{2}$ oxygen pressure at the forefront of specimen (bar), being the outlet pressure of $1 \mathrm{bar}, \mathrm{K}$ is the intrinsic oxygen permeability $\left(\mathrm{m}^{2}\right)$.

\subsubsection{Water permeability}

The water permeability uses the permeability cell, in a similar way and with in the same specimen. The water permeability coefficient can be determined as follow:

$\mathrm{k}_{\mathrm{w}}=\frac{\mathrm{d}_{\mathrm{p}}^{2} \cdot \delta}{2 \cdot \mathrm{h} \cdot \mathrm{t}}$

where $k_{w}$ is the water permeability coefficient $\left(\mathrm{m} \mathrm{s}^{-1}\right), \mathrm{d}_{\mathrm{p}}$ water penetration depth $(\mathrm{m}), \delta$ absorption of the test specimen (open porosity), $\mathrm{t}$ time that took to penetrate to the depth $\mathrm{d}_{\mathrm{p}}$, and $\mathrm{h}$ is the height of water column $(\mathrm{m}), 1 \mathrm{bar}=10.207 \mathrm{~m}$ of water column.

\subsubsection{Chloride diffusion test}

This test method consists of determining the depth of penetration of chloride ions through $50 \mathrm{~mm}$ thick slices of $110 \mathrm{~mm}$ nominal diameter cylinders (Fig. 4). A potential difference of $30 \pm 0.2 \mathrm{~V}$ is maintained across the specimen. One face is immersed in a sodium chloride and sodium hydroxide solution, the other in a sodium hydroxide solution. The chloride diffusion coefficient can be calculated using the following equation:

$\mathrm{D}=(\mathrm{RTL} / \mathrm{zFU}) \cdot\left[\mathrm{X}_{\mathrm{d}}-\left(\alpha \sqrt{ } \mathrm{X}_{\mathrm{d}}\right) / \mathrm{t}\right]$

where

$\alpha=2 \sqrt{ }(\mathrm{RTL} / \mathrm{zFU}) \cdot \operatorname{erf}^{-1}\left(1-2 \mathrm{C}_{\mathrm{d}} / \mathrm{C}_{\mathrm{o}}\right)$

$\mathrm{D}$ is the diffusion coefficient $\left(\mathrm{m}^{2} / \mathrm{s}\right), \mathrm{z}$ absolute valence of the ion involved, for chloride ion, $\mathrm{z}=1$, F Faraday constant, $\mathrm{F}=9.648 \times 104 \mathrm{~J} /(\mathrm{V} \mathrm{mol}), \mathrm{U}$ absolute potential difference $(\mathrm{V}), \mathrm{R}$ constant of ideal gases, $\mathrm{R}=8.314 \mathrm{~J} /(\mathrm{K} \mathrm{mol}), \mathrm{T}$ solution temperature $(\mathrm{K}), \mathrm{L}$ thickness of specimen $(\mathrm{m}), \mathrm{X}_{\mathrm{d}}$ depth of penetration (m), $t$ duration of the test $(\mathrm{s}), \operatorname{erf}^{-1}$ inverse of error function, $c_{d}$ chloride ion concentration with which the colour changes, and $\mathrm{c}_{\mathrm{o}}$ is the concentration of chloride ion in the sodium chloride solution.

\subsubsection{Durability aging test}

The aging test performed consists of twelve cycles; each cycle has four steps and one conditioning period (Fig. 5; Table 7). The different phases have been selected to simulate dry heat, cold weather and wet heat
Table 4 Concrete mix proportions per cubic meter of concrete used in phase A

\begin{tabular}{llll}
\hline Control mix & & \multicolumn{2}{l}{ Concrete mixtures with ceramic wastes } \\
\hline Portland cement & $350.0 \mathrm{~kg}$ & Portland cement & $280.0 \mathrm{~kg}$ \\
Coarse aggregate & $1084.0 \mathrm{~kg}$ & Ceramic waste powder & $70.0 \mathrm{~kg}$ \\
Fine sand & $135.4 \mathrm{~kg}$ & Coarse aggregate & $1084.0 \mathrm{~kg}$ \\
Sand & $564.0 \mathrm{~kg}$ & Fine sand & $135.4 \mathrm{~kg}$ \\
Water & 218.51 & Sand & $564.0 \mathrm{~kg}$ \\
W/C & 0.6 & Water & 218.51 \\
\hline
\end{tabular}


Table 5 Gradation and physical characteristics of aggregates used in phase B

\begin{tabular}{lllll}
\hline Sieve size & \multicolumn{4}{l}{ Cumulative percentage passing } \\
\cline { 2 - 5 } & \multicolumn{2}{c}{$\begin{array}{l}\text { Sand } \\
\text { Ceramic } \\
\text { sand }\end{array}$} & $\begin{array}{l}\text { Coarse } \\
\text { aggregate }\end{array}$ & $\begin{array}{l}\text { Ceramic coarse } \\
\text { aggregate }\end{array}$ \\
\hline 25.4 & 100 & 100 & 100 & 100 \\
19.0 & 100 & 100 & 100 & 100 \\
12.7 & 100 & 100 & 97.1 & 99.2 \\
$9.5 \mathrm{~mm}$ & 100 & 100 & 76.2 & 72.2 \\
$4.76 \mathrm{~mm}$ & 98.6 & 99.0 & 13.5 & 2.8 \\
$2.38 \mathrm{~mm}$ & 78.2 & 71.9 & 4.9 & 0.7 \\
$1.19 \mathrm{~mm}$ & 58 & 48.8 & 4.0 & 0.6 \\
$590 \mu \mathrm{m}$ & 38.6 & 31.5 & 3.4 & 0.5 \\
$297 \mu \mathrm{m}$ & 21.6 & 19.0 & 2.7 & 0.5 \\
$149 \mu \mathrm{m}$ & 9.6 & 9.6 & 2.0 & 0.4 \\
$74 \mu \mathrm{m}$ & 4.4 & 4.1 & 1.3 & 0.3 \\
Density $\left(\mathrm{kg} / \mathrm{m}^{3}\right)$ & 2610 & 2210 & 2643 & 2263 \\
Water & 1.5 & 6.1 & 1.4 & 6.0 \\
absorption $(\%)$ & & & & \\
\hline
\end{tabular}

Table 6 Concrete mix proportions per cubic meter of concrete in phase $\mathrm{B}$

\begin{tabular}{llll}
\hline Materials & Control & $\begin{array}{l}\text { MCS_mix } \\
\text { with ceramic } \\
\text { sand }\end{array}$ & $\begin{array}{l}\text { MCCA_mix with } \\
\text { ceramic coarse } \\
\text { aggregate }\end{array}$ \\
\hline CEM-I 42.5 & 350 & 350 & 350 \\
Sand & 861 & - & 861 \\
Ceramic sand & - & 729 & - \\
Coarse aggregate & 958 & 958 & - \\
Ceramic coarse & - & - & 820 \\
$\quad$ aggregate & & & 175 \\
Water & 175 & 175 & 0.5 \\
W/C & 0.5 & 0.5 & \\
\hline
\end{tabular}

and cold. Further the rapid change of temperature from 75 to $-10^{\circ} \mathrm{C}$ and then from -10 to $55^{\circ} \mathrm{C}$ and dropping quickly to $-10^{\circ} \mathrm{C}$ in each cycle to simulate the thermal shock that concrete can suffer. Figure 5 represents the scheduling of daily sequence. Following the curing period, all the specimens were weighed and half of the specimens were submitted to twelve cycles of aging $24 \mathrm{~h}$ long each, the remaining specimens were kept in the curing chamber at constant $21^{\circ} \mathrm{C}$. All specimens were subjected to compressive strength test.

\section{Results and discussion}

3.1 Ceramic powder as partial replacement of cement

\subsubsection{Compressive strength}

The results obtained indicate, as expected, large differences in early curing ages and smaller differences at long curing ages (Fig. 6). The concrete mixture with $20 \%$ of $\mathrm{CB}$ waste has the highest compressive strength performance for all ceramic wastes which means it has higher pozzolanic reactivity. The concrete mixture with WSOF wastes has the worst mechanical performance at early ages, representing $74.8 \%$ of control strength for 7 days curing. For 28 days curing that concrete mixture has almost $80 \%$ of the control strength index. However, for 90 days curing the compressive strength activity index of the WSOF mixture reaches $90.4 \%$. For long curing ages concrete mixtures with $20 \%$ cement replacement has minor the strength loss. Since higher curing temperatures increase the rate of pozzolanic activity pre-fabrication industry may be an ideal way to their employment. This is because higher curing temperatures are used in concrete pre-fabrication for accelerated demoulding.

\subsubsection{Durability performance}

With the exception of the CB mixture which has a 5\% higher vacuum water absorption than the control mixture, all the others have lower vacuum water absorption than the control mixture (Fig. 7). As for the oxygen permeability (Fig. 8) it can seem that two mixes (CB and SW) shows values slightly higher than the control while two others mixes indicate values smaller (WSTF and WSOF). The differences, however, are between 6 and $12 \%$ in comparison with control mix. The results related to water permeability are shown in Fig. 9. All the concrete mixtures reusing ceramic wastes as cement replacement perform better than the control mixture. Different ceramic wastes have different water permeability. WSOF wastes have the lower water permeability and since this wastes have the lower strength index meaning a less dense microstructure the reduction in water permeability may be due to the hydration of unreacted particles during the water permeability test. Chloride 


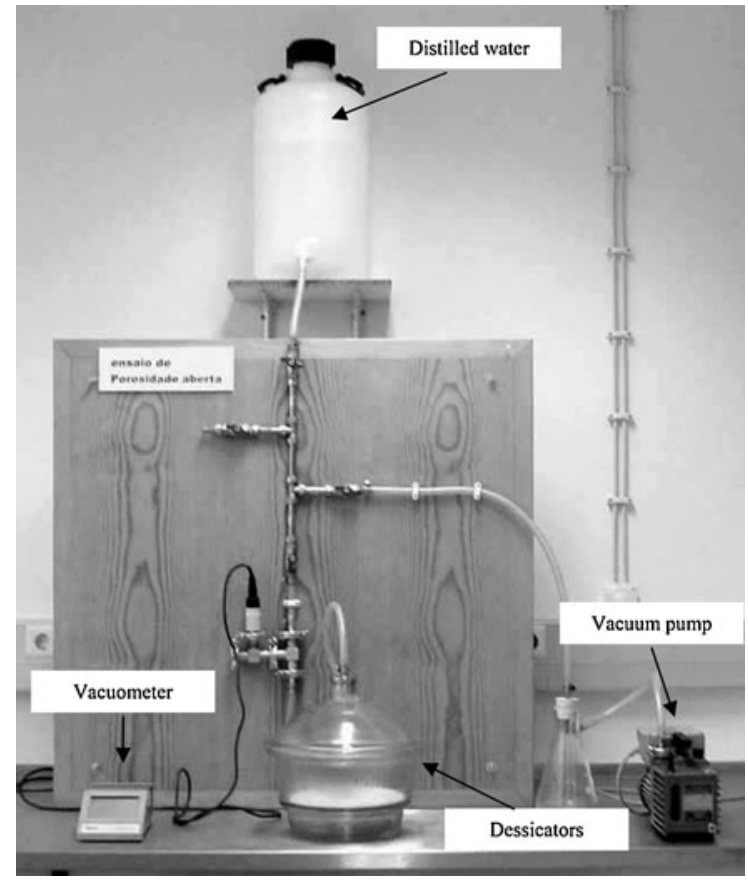

Fig. 2 Water absorption test

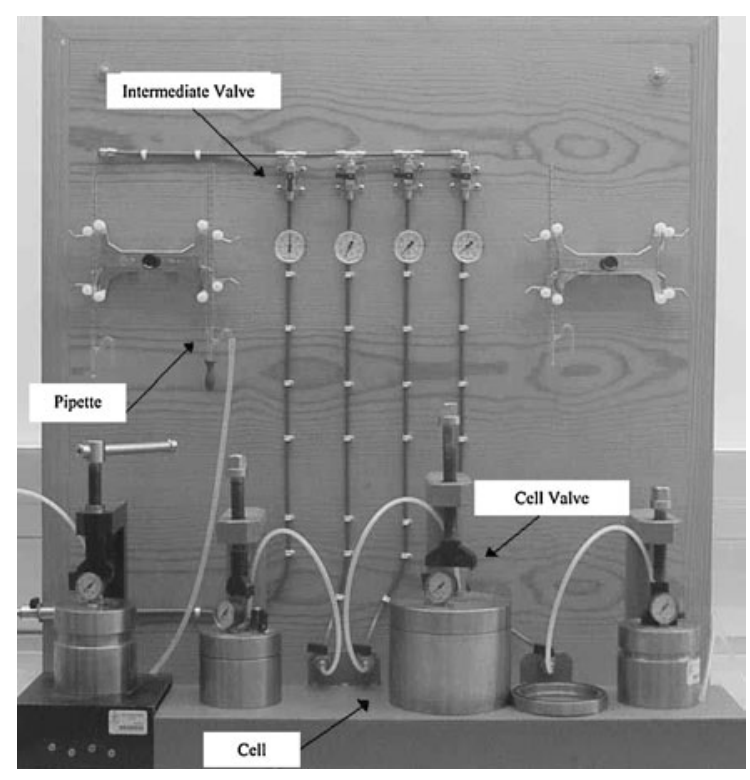

Fig. 3 Oxygen and water permeability cells

ion diffusion is shown in Fig. 10. All mixtures with ceramic wastes performed better than the control, although SW mixture has almost the same diffusion coefficient of the control. As for the durability aging test (Fig. 11), results indicate that all mixtures without exception have higher durability performance which confirms the positive impact of the ceramic additions.

\subsection{Ceramic aggregates replacing traditional aggregates}

\subsubsection{Compressive strength}

The results obtained (Fig. 12) indicate that the strength is higher for concrete with both replacements coarse ceramic aggregate (MCCA) and ceramic sand (MCS) than control concrete with traditional aggregates. This behaviour although confirmed by some authors $[15,16]$, is opposite to the one obtained by others using low percentage crushed brick aggregates $[17,18]$. One explanation for that may be due to the fact that they used brick aggregates with a water absorption level between 16 and 19\%, which is much higher than the water absorption of the ceramic aggregates used in the present investigation (6\%). Another explanation relates to the fact that ceramic aggregates used in this investigation are used in a presaturated state so they can provide water for cement hydration. Nevertheless, the strength performance is higher for concrete mixtures with ceramic sand beyond 14 days curing. As for concrete mixtures with coarse ceramic aggregate a maximum strength level is attained at 28 days curing.

\subsubsection{Durability performance}

Coarse ceramic aggregates based concrete has higher water absorption under vacuum than traditional aggregate concrete (Fig. 13). This difference is $11 \%$ higher for concrete with ceramic sand and it is almost $20 \%$ higher for concrete with coarse ceramic aggregates. Concrete with ceramic sand replacing natural aggregates (MCCA) has higher water absorption than the control concrete but also higher compressive strength. This can be explained by a higher hydration degree of the cement matrix related to the higher water absorption of ceramic sand. As for concrete with coarse ceramic aggregates on can assume that the extra water content lead to a better internal curing than the control concrete. However, this gain is lost by the probable existence of porous interface transition zones near the ceramic aggregates. As for capillary water absorption (Table 8) the differences 
Fig. 4 Chloride diffusion test

Fig. 5 Schedule of the sequence for the durability aging test

Table 7 Durability aging test phases
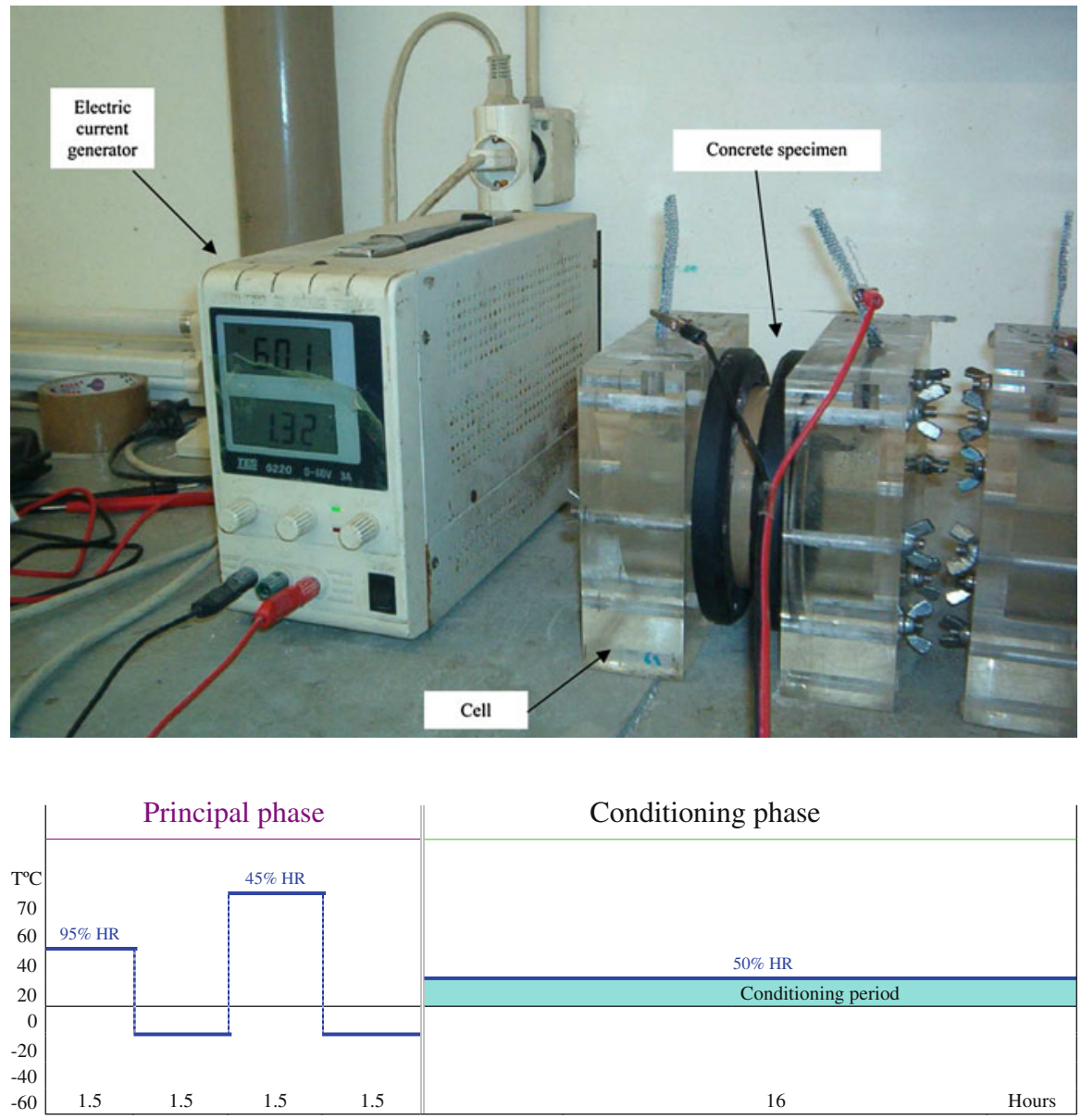

\begin{tabular}{lrcc}
\hline Exposure & Temperature $\left({ }^{\circ} \mathrm{C}\right)$ & Relative humidity $(\%)$ & Duration (min) \\
\hline Principal phase & & & \\
Dry heat & $75 \pm 2$ & 45 & 90 \\
Cold & $-10 \pm 2$ & - & 90 \\
Wet heat & $55 \pm 2$ & 95 & 90 \\
Cold & $-10 \pm 2$ & - & 90 \\
Conditioning phase & & & 960 \\
Conditioning & $23 \pm 2$ & 50 & \\
\hline
\end{tabular}

are rather different since control concrete absorption almost doubles the capillary water absorption of ceramic based concrete which means that ceramic aggregate based concrete has superior durability performance. With the exception of the water permeability (Fig. 14), the results of oxygen permeability and chloride diffusion (Fig. 15) confirms the good performance of ceramic based concrete. As for the durability aging test (Fig. 16) compressive strength reduction is higher for ceramic based concrete. Nevertheless, compressive strength after the aging test is still higher in ceramic based concrete. Therefore, the replacement of traditional sand by ceramic sand in concrete production represents important environmental benefits. It avoids the extraction of large quantities of raw materials from the earth, also avoids energy costs and landfill problems. Since the penetration of oxygen, water, 


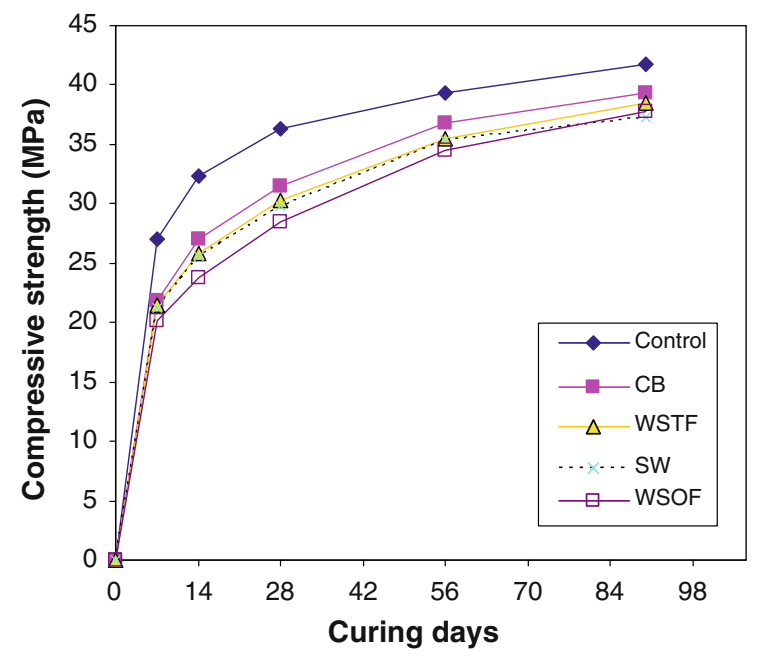

Fig. 6 Compressive strength of concretes with ceramic powder at different curing ages (Control control concrete, $C B$ concrete with ceramic brick powder, WSTF concrete with ceramic powder from stoneware twice-fired, $S W$ concrete with ceramic powder from sanitary ware, WSOF concrete with ceramic powder from stoneware once-fired)

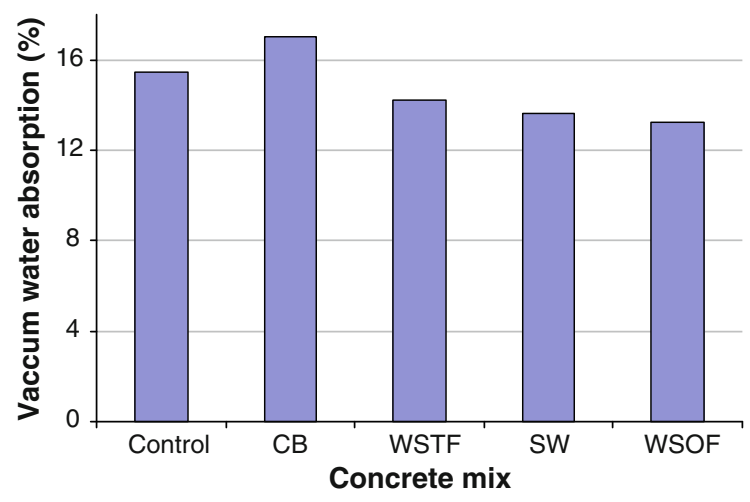

Fig. 7 Water absorption of concretes with ceramic powder (Control control concrete, $C B$ concrete with ceramic brick powder, WSTF concrete with ceramic powder from stoneware twice-fired, $S W$ concrete with ceramic powder from sanitary ware, WSOF concrete with ceramic powder from stoneware once-fired)

chloride and other aggressive ions into concrete is the most important factor in the physical and chemical process of concrete deterioration [19], ceramic sand based concrete does not compromise the durability requirements. The higher ceramic sand concrete durability means less environmental impacts, for instance if we increase concrete durability from 50 to 500 years, we would reduce the environmental impacts by a factor of 10 [20].

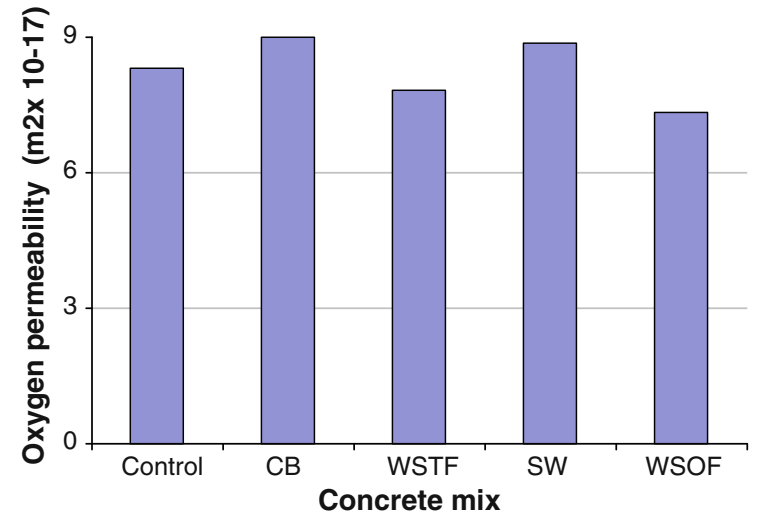

Fig. 8 Oxygen permeability of concretes with ceramic powder (Control control concrete, $C B$ concrete with ceramic brick powder, WSTF concrete with ceramic powder from stoneware twice-fired, $S W$ concrete with ceramic powder from sanitary ware, WSOF concrete with ceramic powder from stoneware once-fired)

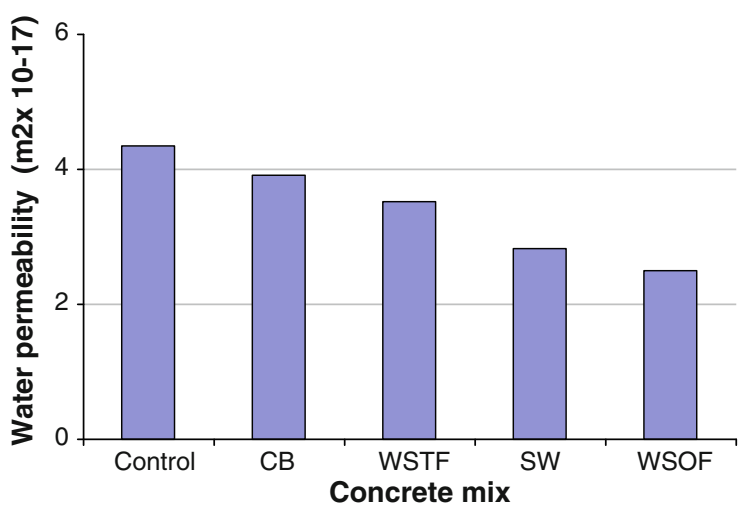

Fig. 9 Water permeability of concretes with ceramic powder (Control control concrete, $C B$ concrete with ceramic brick powder, WSTF concrete with ceramic powder from stoneware twice-fired, $S W$ concrete with ceramic powder from sanitary ware, WSOF concrete with ceramic powder from stoneware once-fired)

\subsection{Environmental advantages related to ceramic wastes in concrete}

Ceramic wastes production in Portugal amounts to almost 400,000 ton/year [1]. Therefore, the replacement of cement by ceramic wastes has the advantage of solving several environmental problems. On one hand, it allows the reduction of carbon dioxide generated by the cement production which is a key aspect in this country. Since European Community agreed to reduce GHG by $8 \%$ (burden sharing agreement) [21], overall target differentiated emissions limitation have been 


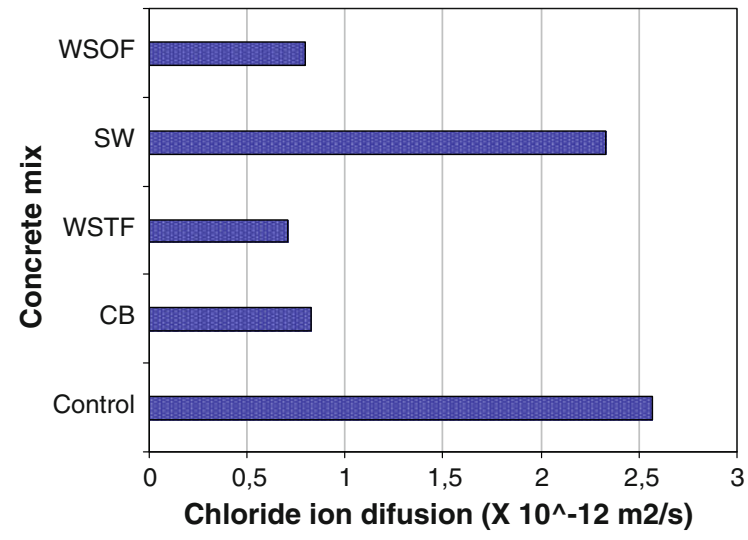

Fig. 10 Chloride ion penetration coefficient of concretes with ceramic powder (Control control concrete, $C B$ concrete with ceramic brick powder, WSTF concrete with ceramic powder from stoneware twice-fired, $S W$ concrete with ceramic powder from sanitary ware, WSOF concrete with ceramic powder from stoneware once-fired)

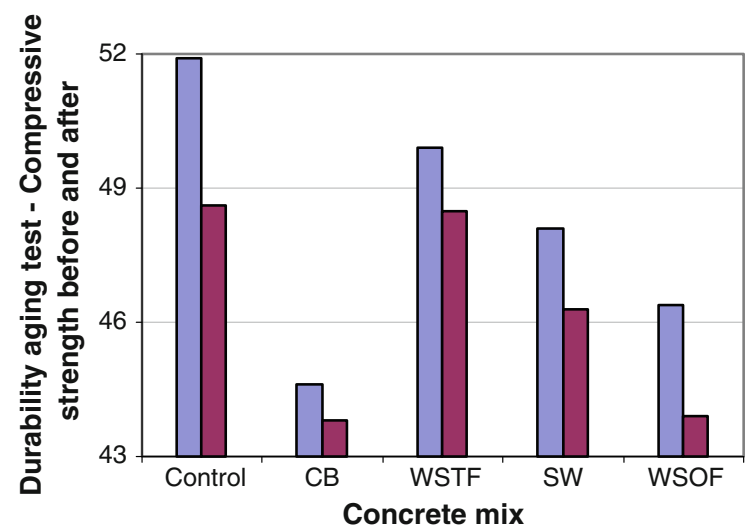

Fig. 11 Compressive strength of concretes with ceramic powder: Before and after the durability aging test (Control control concrete, $C B$ concrete with ceramic brick powder, WSTF concrete with ceramic powder from stoneware twicefired, $S W$ concrete with ceramic powder from sanitary ware, WSOF concrete with ceramic powder from stoneware oncefired)

agreed for each EU-15 members [22]. For Portugal Kyoto commitments implies a reduction of greenhouse gas emissions to no more of $27 \%$ above base-year level until 2012. However in 2001 emissions were 36\%, above Portuguese individual greenhouse gas reduction targets and according to greenhouse gas emissions trends for EU-15 members in 2002, Portugal emissions reach $41 \%$ above 2010 target emissions. Portuguese Portland cement industry produces $10 \mathrm{Mt}$ every year being responsible for almost $10 \%$ of global GHG,

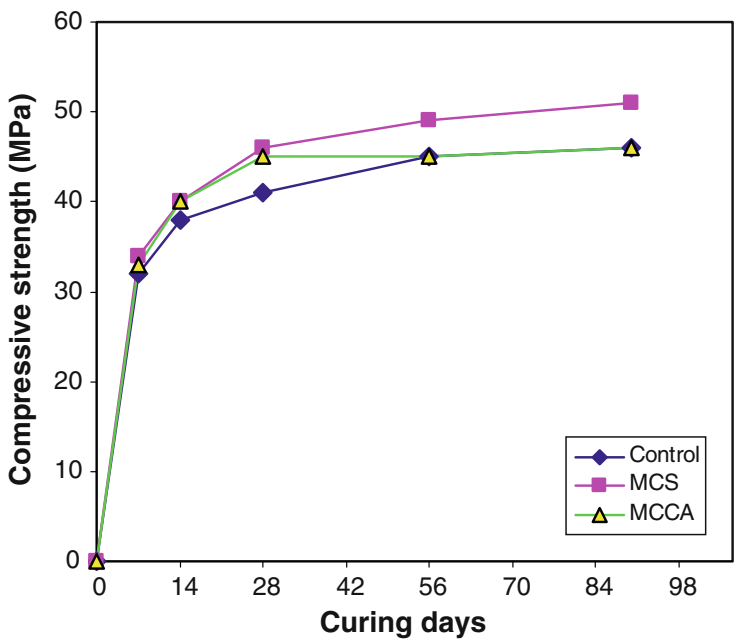

Fig. 12 Compressive strength of concretes with ceramic aggregates at different curing ages (Control control concrete, $M C S$ concrete with ceramic sand replacing natural aggregates, $M C C A$ concrete with ceramic coarse aggregate replacing coarse granite aggregates)

twice the European and world averages [4]. Portugal generates every year only about $0.25 \mathrm{Mt}$ of fly ash from power stations and $0.15 \mathrm{Mt}$ of blast furnace slag which represents only $4 \%$ of Portland cement production. On the other hand, Portugal has serious problems related to biodiversity. According to the World Union for Conservation Portugal is the European country with the higher number of endangered species [1]. To prevent that scenario, large areas of Portuguese land must be protected. Currently Portugal protected areas represent only $7.2 \%$ of the total area. The recent Natura

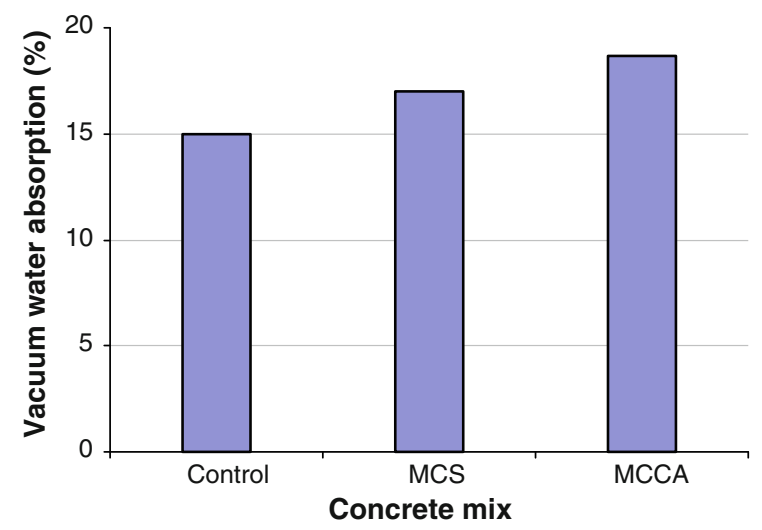

Fig. 13 Concrete vacuum water absorption of concretes with ceramic aggregates (Control control concrete, MCS concrete with ceramic sand replacing natural aggregates, MCCA concrete with ceramic coarse aggregate replacing coarse granite aggregates) 
Table 8 Capillarity water absorption

\begin{tabular}{|c|c|c|c|c|c|c|}
\hline & $\mathrm{A}\left(\mathrm{dm}^{2}\right)$ & $\mathrm{W}_{10}(\mathrm{~g})$ & $\mathrm{W}_{90}(\mathrm{~g})$ & $\left(\mathrm{g} / \mathrm{dm}^{2} \times \min ^{0.5}\right)$ & $\left(\mathrm{kg} / \mathrm{m}^{2} \times \mathrm{h}^{0.5}\right)$ & Average \\
\hline Control & 0.384845 & & & & & \\
\hline 1 & & 1423.42 & 1426.42 & 1.233 & 0.01591 & 0.01819 \\
\hline 2 & & 1425.62 & 1428.96 & 1.372 & 0.01772 & \\
\hline 3 & & 1417.85 & 1421.80 & 1.623 & 0.02095 & \\
\hline \multicolumn{7}{|l|}{ MCS } \\
\hline 1 & & 1338.76 & 1340.46 & 0.698 & 0.00902 & 0.00953 \\
\hline 2 & & 1346.58 & 1348.48 & 0.781 & 0.01008 & \\
\hline 3 & & 1367.38 & 1369.17 & 0.735 & 0.00949 & \\
\hline \multicolumn{7}{|l|}{ MCCA } \\
\hline 1 & & 1335.37 & 1337.00 & 0.670 & 0.00865 & 0.00804 \\
\hline 2 & & 1328.10 & 1329.45 & 0.555 & 0.00716 & \\
\hline 3 & & 1330.08 & 1331.65 & 0.645 & 0.00833 & \\
\hline
\end{tabular}

Fig. 14 Concrete permeability of concretes with ceramic aggregates (Control control concrete, $M C S$ concrete with ceramic sand replacing natural aggregates, MCCA concrete with ceramic coarse aggregate replacing coarse granite aggregates)

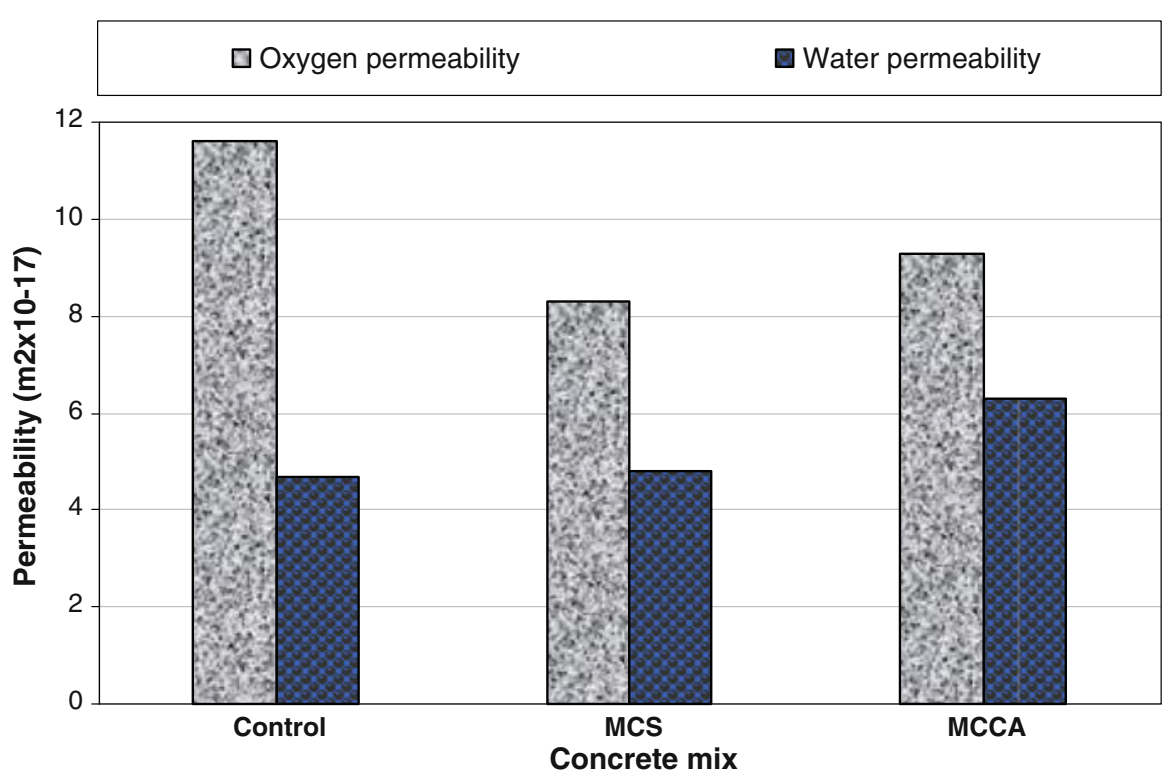

2000 Network (Directiv Birds and Habitats) proposal means a protected area to $14.1 \%$. So that would mean a protected area of $21.3 \%$ for conservation purposes. Still the areas under the Natura 2000 Network, is no more than a balance measure between the areas needed for urban planning and for forest and agricultural production. In fact some authors believe that to prevent species extinction in an effective manner, much more protected area would be needed, about $50-70 \%$ of the total area [23]. According to Myers [24] Portugal needs to protect $77 \%$ of is land area in order to prevent species extinction. That represents a area much bigger than the area needed for Natura 2000 Network. If we think of the areas needed for wastes disposal, we clearly understand the importance of avoiding land filled wastes by reusing ceramic wastes in concrete.

\section{Conclusions}

Results show that concrete with ceramic waste powder has minor strength loss that is dependent on the pozzolanic reactivity of the different ceramic wastes. Results also show that despite this strength loss these 


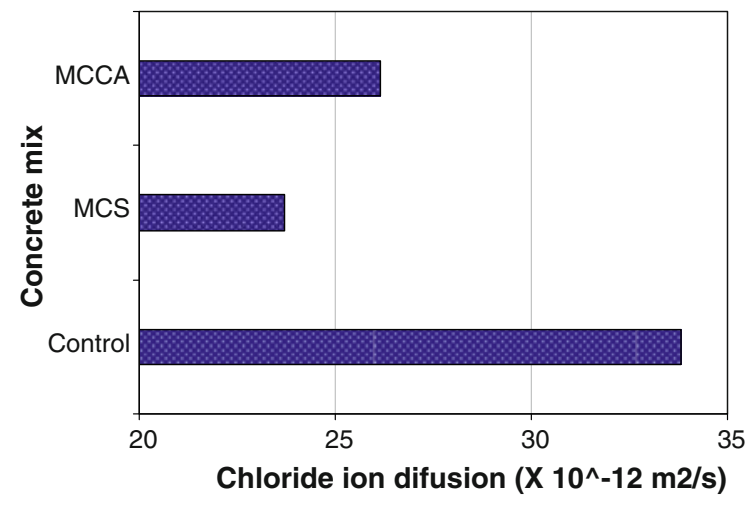

Fig. 15 Chloride ion penetration coefficient of concretes with ceramic aggregates (Control control concrete, MCS concrete with ceramic sand replacing natural aggregates, MCCA concrete with ceramic coarse aggregate replacing coarse granite aggregates)

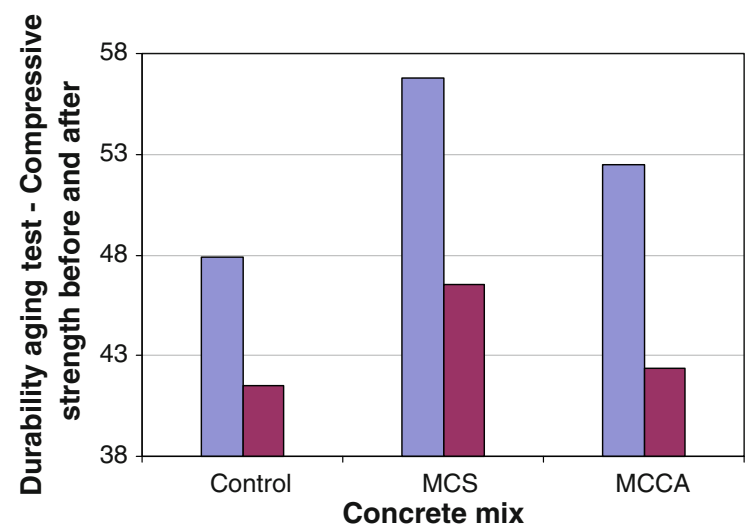

Fig. 16 Compressive strength of concretes with ceramic aggregates: Before and after the durability aging test (Control control concrete, $M C S$ concrete with ceramic sand replacing natural aggregates, $M C C A$ concrete with ceramic coarse aggregate replacing coarse granite aggregates)

concretes possess increase durability performance. Therefore, the replacement of traditional sand by ceramic sand is a good option because does not imply strength loss and has superior durability performance. As for the replacement of traditional coarse aggregates by ceramic coarse aggregates, the results are very promising but underperformed in water absorption under vacuum test. These concretes possess a very good behaviour especially concerning capillary water absorption. Using ceramic wastes in concrete can solve several environmental problems, by one hand avoiding the extraction of large quantities of raw materials from the earth and also reducing GHG emissions generated in the clinker production, and by another reducing the landfill areas that otherwise would be occupied by this wastes.

\section{References}

1. Fernandes M, Sousa A, Dias A (2004) Environmental impact and emissions trade. Ceramic industry. A case study. Portuguese Association of Ceramic Industry APICER

2. Mehta PK (2001) Reducing the environment impact of concrete. Concrete can be durable and environmentally friendly. Concr Int 10:61-66. http://www.ce.berkeley.edu/ $\sim$ paulmont/CE60New/Concrete\%20and\%20the $\% 20$ Environment.pdf

3. Meyer C (2009) The greening of the concrete industry. Cem Concr Compos 31:601-605. doi:10.1016/j.cemconcomp. 2008.12.010

4. Gartner E (2004) Industrially interesting approaches to low- $\mathrm{CO}_{2}$ cements. Cem Concr Res 34:1489-1498. doi: 10.1016/j.cemconres.2004.01.021

5. Lavat A, Trezza M, Poggi M (2009) Characterization of ceramic roof tile wastes as pozzolanic admixture. Waste Manage 29:1666-1674. doi:10.1016/j.wasman.2008.10.019

6. Naceri A, Hamina M (2009) Use of waste brick as a partial replacement of cement in mortar. Waste Manage 29:23782384. doi:10.1016/j.wasman.2009.03.026

7. Puertas F, Garcia-Diaz I, Barba A, Gazulla M, Palacios M, Gomez M, Martinez-Ramirez S (2008) Ceramic wastes as alternative raw materials for Portland cement clinker production. Cem Concr Compos 30:798-805. doi:10.1016/ j.cemconcomp.2008.06.003

8. Binici H (2007) Effect of crushed ceramic and basaltic pumice as fine aggregates on concrete mortar properties. Constr Build Mater 21:1191-1197. doi:10.1016/j.conbuildmat.2006.06.002

9. Cachim P (2009) Mechanical properties of brick aggregate concrete. Constr Build Mater 23:1292-1297. doi:10.1016/ j.conbuildmat.2008.07.023

10. NP EN 12620 (2004) Aggregates for concrete. Portuguese Laboratory of Civil Engineering-LNEC

11. NP EN 197-1 (2001) Cement-Part 1: Composition, specifications and conformity criteria for common cements. Portuguese Laboratory of Civil Engineering-LNEC

12. NP EN 12350-2 (2002) Testing fresh concrete. Part 1: Slump test. Portuguese Laboratory of Civil EngineeringLNEC

13. NP EN 12390-3 (2003) Testing hardened concrete. Part 3: Compressive strength. Portuguese Laboratory of Civil Engineering-LNEC

14. LNEC E393 (1970) Concrete: determination of capillarity water absorption

15. Guerra I, Vivar I, Llamas B, Juan A, Moran J (2009) Ecoefficient concretes: the effects of using recycled ceramic material from sanitary installations on the mechanical properties of concrete. Waste Manage 29:643-646. doi: 10.1016/j.wasman.2008.06.018

16. Lopez V, Llamas B, Juan A, Moran J, Guerra I (2007) Ecoefficient concretes: impact of the use of white ceramic 
powder on the mechanical properties of concrete. Biosyst Eng 96:559-564. doi:10.1016/j.biosystemseng.2007.01.004

17. Brito J, Pereira A, Correia J (2005) Mechanical behaviour of non-structural concrete made with recycled ceramic aggregates. Cem Concr Compos 27:429-433. doi:10.1016/ j.cemconcomp.2004.07.005

18. KhatibJ(2005)Propertiesofconcreteincorporatingfinerecycled aggregate. Cem Concr Res 35:763-769. doi:10.1016/j.cem conres.2004.06.017

19. Oh B, Cha S, Jang B, Jang S (2002) Development of highperformance concrete having high resistance to chloride penetration. Nucl Eng Des 212:221-231. doi:10.1016/ S0029-5493(01)00484-8

20. Mora E (2007) Life cycle, sustainability and the transcendent quality of building materials. Build Environ 42: 1329-1334. doi:10.1016/j.buildenv.2005.11.004
21. Directive 203/87/Ec (October 2003) European Union $\mathrm{CO}_{2}$ emissions trading scheme

22. European Environmental Agency (2008) Greenhouse gas emission trends and projections in Europe. EEA technical report no. 5/2008

23. Soulé M, Sanjayan M (1998) Conservation targets: do they help? Science 279:2060-2061. doi:10.1126/science.279. 5359.2060

24. MyersN,MittermeierR,MittermeierC,FonsecaG,KentJ(2000) Biodiversity hotspots for conservation priorities. Nature 403: 853-858. http://www.ithaca.edu/faculty/rborgella/environment/ biodiversity_hotspot.pdf 